\title{
Do landscape patterns reflect ecosystem service provision? - A comparison between pro- tected and unprotected areas throughout the Lake Neusiedl region
}

\author{
Michael Kuttner, Anna Schneidergruber \& Thomas Wrbka
}

Keywords: ecosystem services, landscape indices, biodiversity, green infrastructures, sustainability

\section{Abstract}

Nowadays, anthropogenic landscape fragmentation and land-use change are recognized as major driving forces for the ongoing worldwide loss of biodiversity. Though nature conservation areas, such as Austria's national parks, serve as retreat habitats for a broad range of biota, they are embedded in a complex of landscapes where diverse conflicts of interests meet, for instance tourism, agriculture and nature conservation. As a first step to improving the multifunctional quality of landscapes in terms of connectivity and flows of energy, material and information across the boundaries of protected zones, the status quo of such landscape mosaics has to be evaluated. The main aim of this study was to test if protected areas generally supply a higher share of environment-related ecosystem services than the surrounding landscape. We also investigated to which extent the structural composition and configuration of landscape sections reflects their volume of ecosystem service provision. We selected our study sites within the Austrian-Hungarian transnational study region around Lake Neusiedl and developed a methodological framework for assessing and mapping ecosystem services based on expert knowledge, spatial information and field data. The crucial linkage between landscape structure and its contribution for sustaining distinct ecological key functions was investigated through comprehensive use of landscape metrics, habitat and connectivity mapping. We were able to verify that levels of ecosystem service provision as well as the share and function of ecologically viable landscape elements were higher within the national park and that a statistical correlation between the aforementioned assessments exists. The outcomes of this study may support local stakeholders with valuable information on the service provision capacity and functional state inside and outside protected landscapes and illustrate hot and cold spots of network patterns. This in turn will allow the development of well-focused and efficient planning measures to strengthen ecosystematic functioning in terms of sustainable landscape development vis-à-vis society.

\section{Profile}

Protected area

Lake Neusiedl / Fertö Hanság Nati-

onal Park

Country

Austria \& Hungary

\section{Introduction}

In recent decades the demand for natural resources has grown considerably due to exponential economic growth, resulting in an enormous pressure on the earth's ecosystems. As a consequence, our society is faced with various negative impacts on the environment, such as habitat loss, fragmentation and degradation, climate change, biological invasions, overexploitation and pollution at global, national and regional level. European cultural landscapes in particular are characterized by a high level of anthropogenic fragmentation and habitat loss which are known major reasons for the decline of biodiversity in industrialized countries and also have a negative influence on ecosystem service provision (Walz \& Syrbe 2013). Old cultural landscapes, on the other hand, which have been shaped and used for centuries, like the region around Lake Neusiedl, are composed of a mosaic of different habitat types reflected in a highly diverse landscape structure. Based on these geometrical aspects, which can also be regarded as frozen processes (Wrbka et al. 2004), the crucial relationship between structural patterns and functional indicators in landscapes has been stressed repeatedly (Forman 1995; Turner et al. 2001; Moser et al. 2002; Blaschke 2006; Walz 2011). Such multifunctional landscapes not only share a rather high potential for biodiversity and ecosystem functioning but are also beneficial for society (Otte et al. 2007). The concept of ecosystem services is said to have great potential for adding value to current conservation approaches, in particular for local and regional planning (Maes et al. 2012; Chan et al. 2006; Daily \& Matson, 2008; Nelson et al. 2009; Egoh et al. 2009). However, this potential remains poorly explored across Europe (Haslett et al. 2010; Harrison et al. 2010). Therefore we have investigated the relation of two promising options to provide a knowledge basis to meet the needs of sustainable landscape development and conservation management inside and outside protected areas. While Kuttner et al. 2013 introduced an assessment of structural landscape functionality that has been devel- 


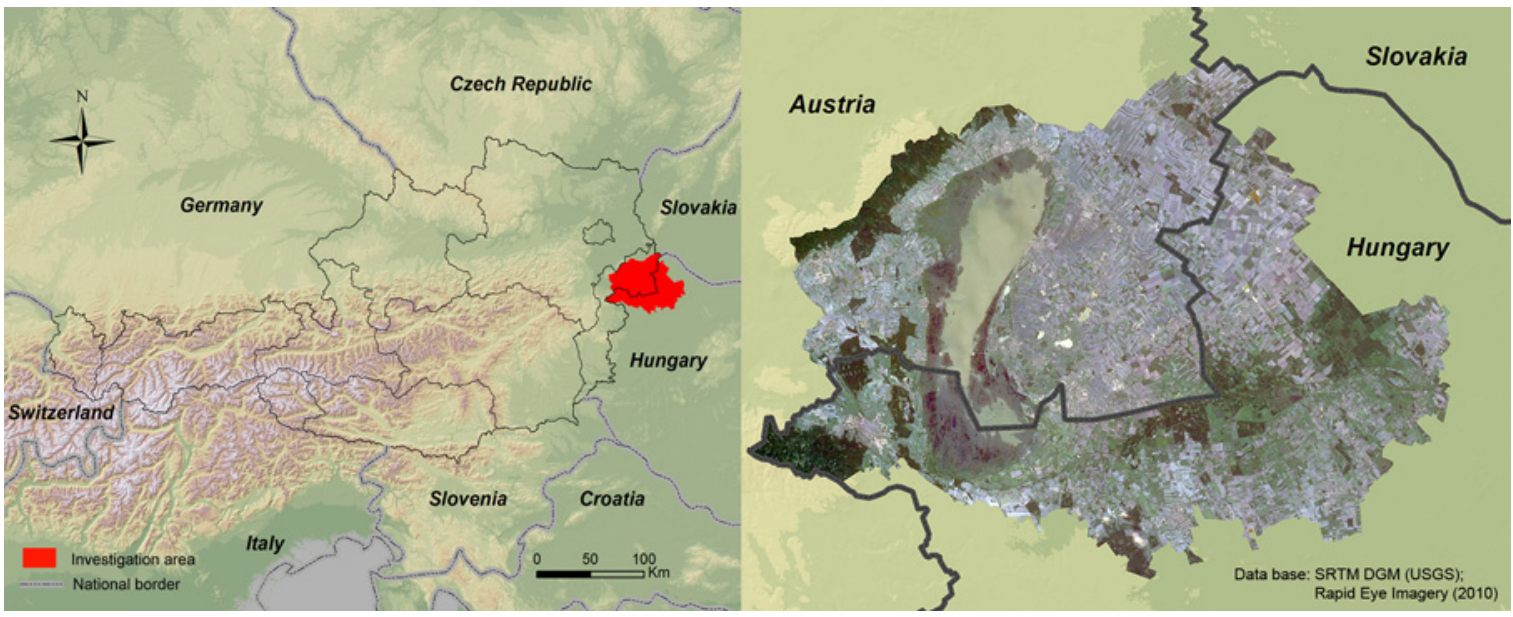

Figure 1 - Location of the study area within the cross-border region of Austria and Hungary.

oped to provide a comprehensive overview of location and quality of ecologically valuable landscape elements and networks, Hermann et al. (2014) created a flexible approach for mapping and spatio-thematic aggregation of various ecosystem services (ESS). Both assessments were conducted on the same sample plots throughout the transnational study region around Lake Neusiedl.

The main aim of our study was to find out if ecosystem service provision differs significantly, depending on status and category of protection, with a special focus on Lake Neusiedl / Fertö Hanság National Park (NP). As stated by Syrbe \& Walz (2012), structural configuration and land-use regimes have a strong influence on several ecological key processes which have been quantified by ESS evaluation. We also tested if a statistical relation existed between the results of the former studies and identified hot and cold spots of ESS supply, which we subdivided into the main groups of Provision, Habitat and Regulation services. We tested the strength and quality of coherence between them and the outcomes of the structural assessment on landscape functionality. Innovative conservation assessment and planning may benefit from this approach because it allows for an integrative evaluation of conservation areas and their contribution to human wellbeing (Chan et al. 2006; Egoh et al. 2008).

\section{Study region}

The investigation area of approx. $2015 \mathrm{~km}^{2}$ is located on both sides of the border between Hungary and Austria (see Figure 1). Therein the cross-border Lake Neusiedl / Fertö-Hanság NP, founded in 1993, covers an area of around $90 \mathrm{~km}^{2}$ in Austria and $230 \mathrm{~km}^{2}$ in Hungary. At $114 \mathrm{~m}$, Austria's lowest elevation $\left(47^{\circ} 44.1^{\prime} \mathrm{N}, 16^{\circ} 51.8^{\prime} \mathrm{E}\right)$ is situated in the centre of the study area near the village of Apetlon.

The predominant climate is Pannonian, with annual precipitation rates around $600-800 \mathrm{~mm}$ and an annual mean temperature of $>9{ }^{\circ} \mathrm{C}$ (ZAMG 2002). The continental lake basin between the Alps and the Carpathians is a north-western overhang of the Small Pannonian Plain at the foothills of the Leithagebirge and the Ruster Hügelland.

Lake Neusiedl and a series of small satellite lakes on the eastern part, the Seewinkel area, constitute the westernmost alkali lakes in Europe and the seminatural zone around them still forms Europe's second largest reed wetland vegetation, which is one of the most important bird sanctuaries in Central Europe, both for breeding and migratory birds. Beyond the wetlands the area includes extremely rich habitats, presenting a transition zone between the mountain ranges and the lowlands of the Pannonian Basin. From the unique dry alkaline steppe up to the closed deciduous forests, a series of different vegetation types results in a high level of landscape diversity, also promoting biodiversity as such. Due to the biocultural richness of the region, a series of other nationally and internationally protected areas, such as species management areas (IUCN Cat. IV) and protected landscapes (IUCN Cat. V) (Dudley 2008), Natura 2000 sites and a transnational biosphere reserve that covers the entire surface area of the lake have been created here. While these sites largely overlap the outer zones of the NP, they add support to sustainable landscape management strategies inside the park. In contrast, the rather dispersed Natura 2000 network ensures target-oriented protection of single species, e.g. the Great Bustard (Otis tarda), and their required core habitats beyond the NP boundaries. Further, the entire Lake Neusiedl plus its adjacent reedbelt, covering a total area of over $440 \mathrm{~km}^{2}$, have been added to the list of internationally important wetland ecosystems by the RAMSAR convention in 1983. Finally, the Fertö-Lake Neusiedl region was designated a UNESCO World Heritage Site in 2001 to foster the preservation of the traditional cultural landscape and to support sustainable regional development. 


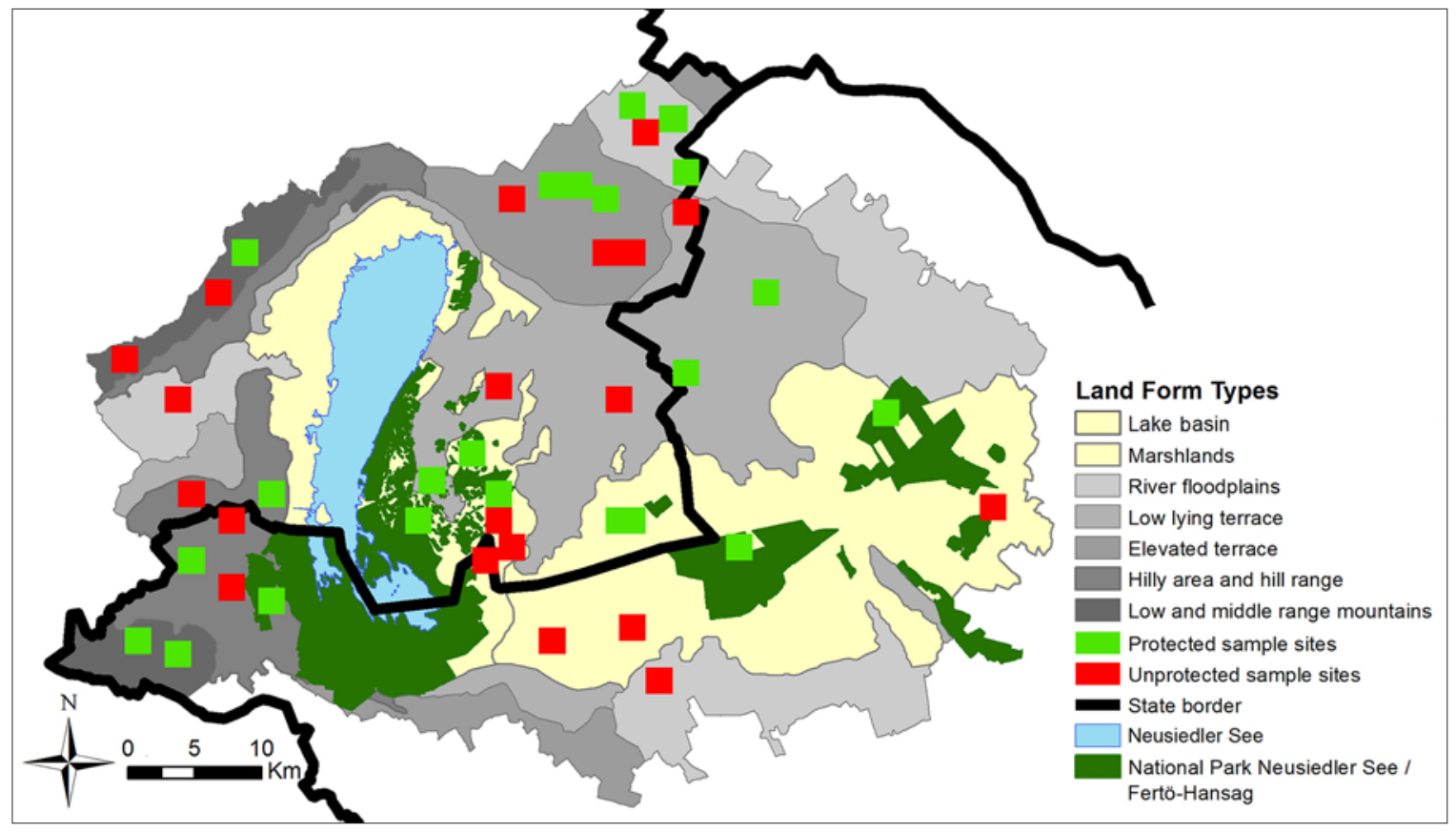

Figure 2 - Overview of the entire study region, including the division into LFTs and location of local sample sites. Lake basin and Marshlands are highlighted on the map and cover the area of the NP.

\section{Methods}

\section{Landscape division and local site sampling} procedure

In order to reach statistically neat results that could be scaled up and compared, we developed a common spatial reference framework, including a nested sampling design for the selection of test sites, which followed several stratifications. As a prerequisite, the region was subdivided into seven Land Form Types (LFTs) (Konkoly-Gyuró et al. 2010). These LFTs are expressed by geomorphological peculiarities that form the characteristic shapes of the target region and result in greatly varying land-use strategies: Lake basin, Marshlands, River floodplains, Low lying terrace, Elevated terrace, Hilly area and hill range, Low and middle-range mountains. Within each LFT, we randomly selected six $2 \times 2 \mathrm{~km}^{2}$ sample sites by applying a predefined set of exclusion criteria, including inaccessibility of NP core zones or minimum distance to adjacent villages. The final set consisted of a balanced proportion of sites located inside or outside protected areas (Figure 2).

Assessment of structural landscape functionality

We delineated single landscape elements across all sample sites through object-based image analysis of the latest available orthophotos and manually corrected spatial misclassifications afterwards by onscreen digitizing. Then we applied a key for visual land cover interpretation, where the CORINE land cover interpretation system served as thematic basis to identify 65 different land cover classes. The resulting land cover maps were used for landscape structure analysis, where we first calculated a comprehensive set of
46 landscape metrics at class level using Fragstats 3.3 (McGarigal et al. 2002) and computationally reduced them to 21 by sorting out all highly correlated metrics after conducting a rank-based correlation analysis in $\mathrm{R}$ 2.7.1 (R Development Core Team 2008). Then we performed a Principal Component Analysis to detect the metrics that emerged as most important in describing variance throughout the input dataset. We then compared these outcomes with other recent literature and reduced the final set of metrics to 13 . This core set of indices is subdivided into AREA (mean patch area; largest patch; total class area), SHAPE (area-weighted mean shape; landscape shape index; mean fractality), CONNECTIVITY (mean proximity; connectance; contiguity), ISOLATION (patch density; Euclidean nearest neighbour; aggregation index) and CORE (mean core area). For a differentiated assessment of the landscape's ecological state based on its underlying structural features, we sectioned the different land cover classes into six discrete functional groups (connecting corridors, dissecting corridors, valuable matrix, disturbed matrix, artificial matrix, stepping stones) and set up a classification scheme where positive or negative relations between the selected metrics and each functional group were assigned in terms of quantifying structural landscape functionality. In case of ambiguous or negligible relations, we excluded the relevant metrics from subsequent group calculations. In order to reach one final functionality value per sample site, we transformed and rescaled metric values per group, with a range of $0-100$ for positively correlated or 100 - 0 for negatively correlated metrics, and summarized their outcomes per site. Further, to detect most valuable Green Infrastructure (GI) elements and ecologically valuable network structures, 

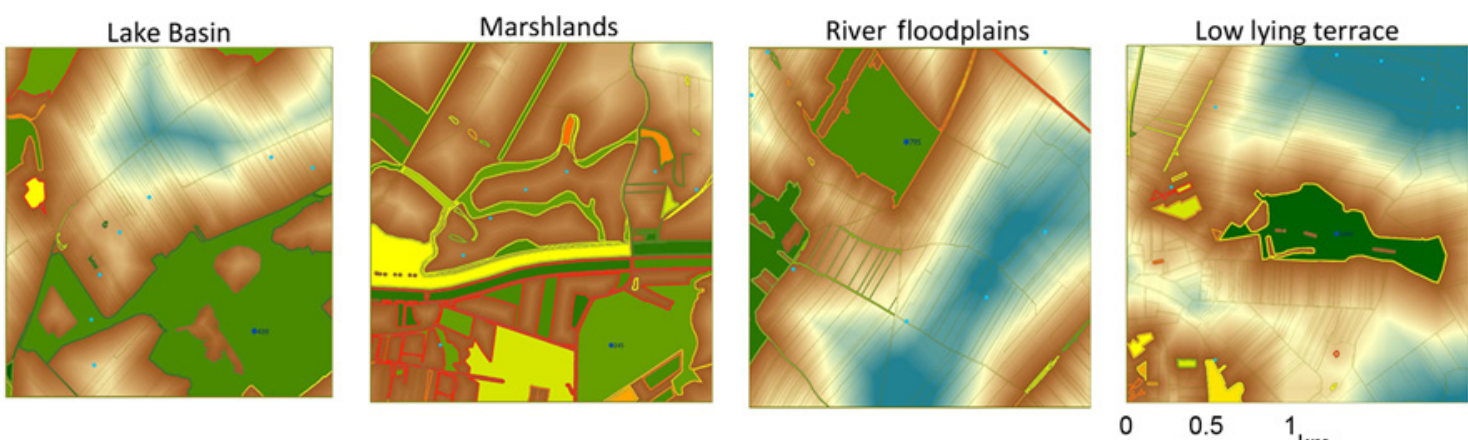

Elevated terrace
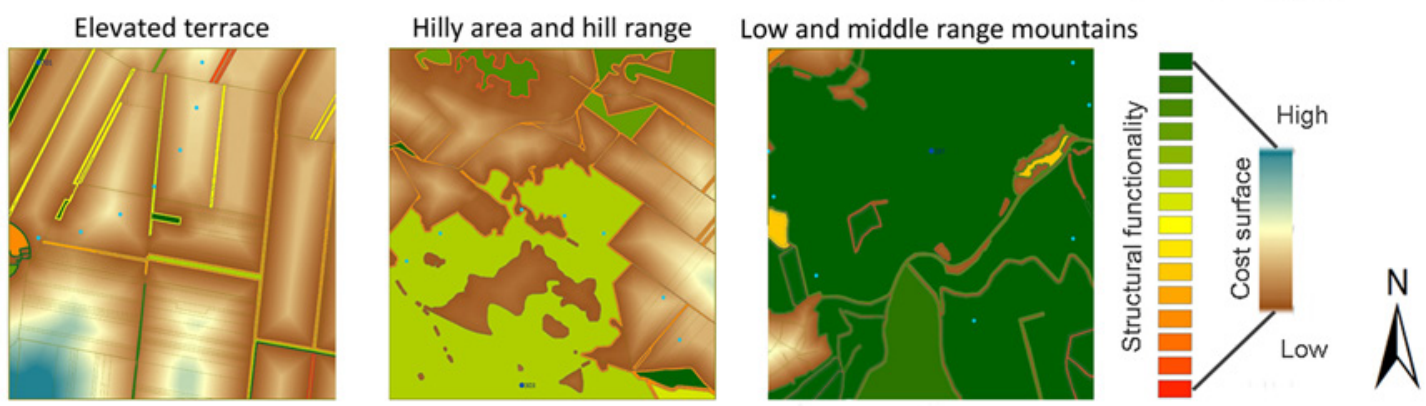

Figure 3 - Combined landscape functionality maps for each LFT, visualizing GI networks and results cost surface modeling approach.

we performed a morphological spatial pattern analysis plus additional cost surface mapping for a predefined virtual species group we called specialists, which would require less or non-disturbed parts of the landscape as their living space. At this, we set up a series of seven way points located at a standardized distance $(=1 \mathrm{~km})$ from the centroid point of the largest GI element per sample plot and simulated least cost path walks to each point. The parameterization quantifying accessibility of the various landuse types to cross have been specifically suited to our target species group and consequently one final least cost path value per plot has been generated by calculating the mean out of the seven single walks. For further details on the previously described technical part of this study, please also refer to Kuttner et al. (2013).

\section{Evaluation of ecosystem services}

We also assessed and mapped 14 ESS within the aforementioned spatial reference framework for each sample site of the single LFTs. The ESS were grouped into three main service categories: Regulation (local climate regulation, disturbance prevention, water regulation, water supply, soil retention, soil formation, nutrient regulation, pollination), Habitat (sanctuary, nursery) and Provision (wild plants and game, raw materials, genetic resources, medicinal resources) (mainly adapted from de Groot 2006). To distinguish different service providing units, we used the Broader Habitat Type (BHT) classification system (Bunce et al. 2008, 2011). BHTs were linked to their capacities for providing various ESS by an expert-based classification system, on a scale of 0 to 5 , with the highest value denoting the closest general relation between the BHT and its related service. This so-called Broader Habitat
Approach (Hermann et al. 2014) is based on a capacity matrix, with values altered by semi-quantitative field data (qualifiers). These qualifiers describe in-situ characteristics of single service providing units (landscape elements) with regard to their structural peculiarities, management practices and disturbance regimes. We then aggregated the service data into the main service categories and extrapolated them to gain statistically comparable results between the LFTs and protected and unprotected areas.

Interrelation of the assessments and comparison between areas of different protection status

In order to test if the outcomes of the two divergent assessments were pointing in the same direction, we conducted various univariate and multivariate linear regression analyses to identify both single and main ecosystem services that are correlated with structural landscape functionality and the share of green infrastructure networks.

In a separate step we tested if protected landscapes could be distinguished from non-protected areas in terms of service provision by applying a series of One-way Analysis of Variance (ANOVA) tests.

\section{Results}

Results of the structural functionality assessment

The combined outcomes of the structural landscape functionality assessment are represented in Figure 3, including sample GI maps for each LFT. Ecologically most valuable GI networks and corresponding functionality rating, which would serve as potential habitats and migration corridors for the virtual specialist species group, are marked. In the back- 
ground, outcomes of the cost surface modelling approach are outlined, ranging from areas that are easy to cross (brown) to barriers (blue).

\section{Results of the coparison of ESS provision in} protected and unprotected areas

The resulting boxplots (Figure 4) represent LFTbased mean service values for the main categories of Regulation, Habitat and Provision.

The course of the lines is quite similar, reflecting that the three environment-related service categories are positively correlated to each other and that there are no specific trade-offs between them. However, the importance of the single main groups is different. Whereas the main services Regulation and Habitat ranked close to each other, the Provision services resulted in distinctly lower values. Considering the different LFTs, outcomes reflected the high diversity within the study area, from natural and semi-natural areas, such as the shallow lake and its reed beds, the remaining marshland and flood plains, to the extensively used hilly area and the intensive agricultural regions in the low-lying and elevated terraces. Results of ANOVA testing confirmed significant differences $(\mathrm{p} \leq 0.05)$ throughout main service values across the single LFTs.

When comparing main service values of protected and unprotected sites within each LFT, most of them differed significantly. However, of the protected sites only Marshlands and Lake basin resulted in clearly higher values $(\mathrm{F}=6.7902 ; \mathrm{p} \leq 0.001)$ for all ecosystem main services compared to the unprotected sites. These LFTs are particularly interesting with regard to their conservation value as large parts are covered by Lake Neusiedl / Fertö-Hanság NP (see also Figure 2). Another series of ANOVA testings also pointed to significantly increased levels of structural functionality $(p \leq 0.001)$ and share of GI elements $(p \leq 0.05)$ within the NP territory.

\section{Comparison between ecosystem services and structural landscape functionality}

The scatterplots displayed in Figure 5 represent results of three different regression analyses that tested the dependency of main ecosystem services from the outcomes of the survey on structural landscape functionality, which are based on mean values of the single sample sites $(n=41)$. Relations proved to be significant $(p \leq 0.001)$ in all cases and the strength of the statistical models ranged from corr. $r^{2}=0.691$ for the main service Habitat to corr. $\mathrm{r}^{2}=0.737$ for Regulation and corr. $\mathrm{r}^{2}=0.802$ for Provision.

The performance of a stepwise multivariate regression analysis, where all subservice variables $(n=14)$ were chosen as predictors at once, resulted in corr. $\mathrm{r}^{2}=0.875$ for the four service variables of Soil retention (Regulation), Sanctuary (Habitat), Food and Genetic resources (both Provision) for the final model. A second multivariate regression analysis that focused on the relation between subservice values and GI net-

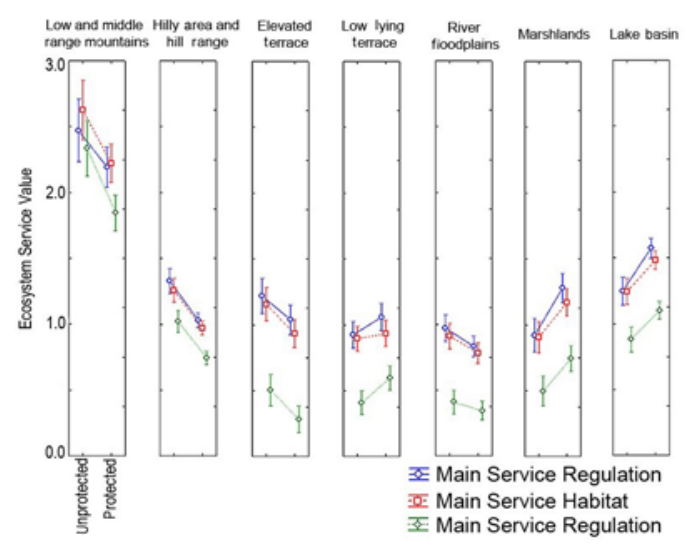

Figure 4-Boxplots of ANOVAs targeting main service distribution between individual LFTs and subdivided into protected and unprotected areas. The NP is located in the LFTs Lake basin and Marsblands.

work area returned corr. $\mathrm{r}^{2}=0.862$ using 8 out of 14 variables. The majority and most influential ones of those, when referring to the summary of the stepwise regression, belonged to the main group of Provision services.

\section{Discussion}

The remarkable higher outcomes of both ESS and structural functionality assessments within the protected sites of the LFTs Marshlands and Lake basin (Figure 4) might be due to the fact that most of these subregions are covered by Lake Neusiedl-Seewinkel / Fertó-Hansàg NP and thus follow a broad conservation concept with core areas and buffer zones. Figure 6 exemplifies the outcomes of the structural functionality and ecosystem service assessments for the LFT Lake basin. However, non-protected areas within these LFTs also range above average in ESS supply, leading to the assumption that large and effectively managed nature reserves support ESS supply beyond its borders. Apart from those cases, the majority of LFTs showed a rather unclear and partly contrasting picture of ESS provision inside and outside local protected zones. There are several possible explanations for this: - Some protected area categories, such as the protected landscapes (IUCN Cat. V) or biosphere reserve buffer zones, only prescribe minor conservation conditions for local land use and forestry.

Other special protection areas, e. g. those under the EU Birds Directive, often follow specific management plans to foster local populations. In the Lake Neusiedl region, protected nesting areas of the Great Bustard (Otis tarda) located in LFT Elevated terrace demand an open and extensively utilized agricultural matrix without high proportions of corridor networks and stepping stone elements. In turn, this leads to comparatively low structural landscape functionality (Kuttner et al. 2013) and mediocre provision of Regulation, Habitat and Provision services in the protected parts of this LFT. 


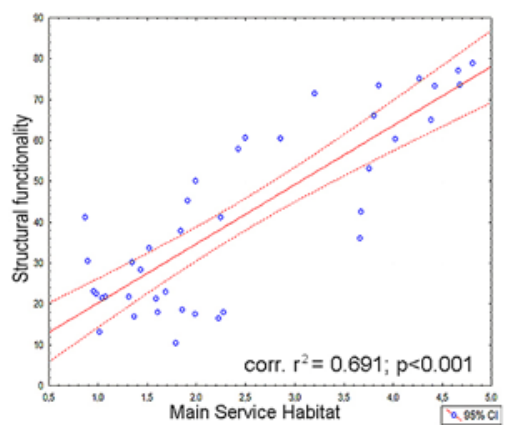

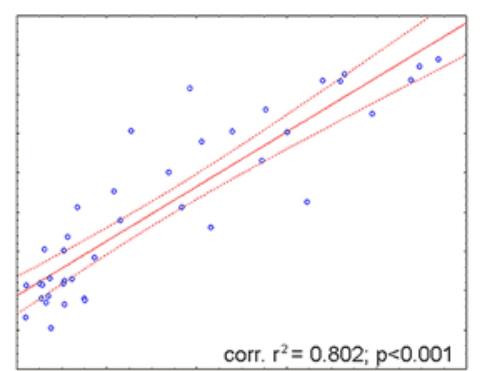

Main Service Provision

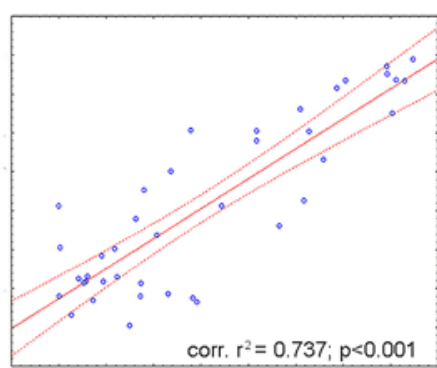

Main Service Regulation

Figure 5 - Three scatterplots visualizing outcomes of linear regression analyses between structural functionality and ecosystem main services.

- Privately owned land like the extensive oak-hornbeam forests in the Leithagebirge region enjoy no protection status. Hence, within the LFT Low and Middle range mountains with its vast private forest stands, the protection status might not be a determining factor for ecological quality and ESS provision. The fact that some of the sample sites within the LFT Elevated terraces also include large privately owned forest areas explains the rather high values within the unprotected areas.

However, ESS provision did not turn out to be significantly higher in some of the protected areas within the single LFTs. Distribution of GI elements and structural functionality values consistently showed higher outcomes. While the investigated ESS main groups are rather highly correlated to the outcomes of the structural assessment, not all of the single subservices showed such strong interdependency and thus cannot be explained by structural proxies only, as Syrbe et al. had already found in 2012. For example, abiotic services such as climate-, nutrient regulation or soil formation shared a rather high service potential in nonprotected but still sustainably managed areas as well. Nevertheless, both assessments are strongly correlated as most ecologically valuable elements share a rather high potential for providing the investigated ESS. As our results confirm, land management generally does not seem to be overexploitative in the region, especially in non-favourable sites (e.g. wooded slopes and wet or dry areas that have not been reclaimed/drained). On the other hand, areas that have been intensively used for decades, such as the LFTs Low terrace and Elevated terrace, performed least well, both in ecosystem service provision and structural functionality. Future management of ecosystems to enhance their functioning and service provision must consider the trade-offs between the different services. While we found positive correlations between ecologically valuable areas and the supply of the environment related services, traditional food production and services of crops and livestock are likely to be higher in intensively used areas (Hermann et al. 2014; Maes et al. 2012).

Our results are congruent with the outcomes of a global study carried out by Naidoo et al. (2006), in which they demonstrated that regions selected to maximize biodiversity do not provide as many ecosystem services as regions chosen randomly. However, it strongly depends on the target of the respective conservation area. Despite the lack of general concordance, win-win areas - regions important for both ecosystem services and biodiversity - could also be identified, especially on smaller scales. However, the results might be biased by the methods chosen to assess ecosystem services. As some services, such as providing a sanctuary, are locally explicit, while other services, such as climate regulation, occur on a regional scale (Hermann et al. 2011), it is difficult to assess a wide range of services within a specific service providing unit, e.g. a conservation area. Bridging the gap between different approaches to conservation and adaptive management of ecosystems to support service provision is part of new global and regional biodiversity policies. However, levels of congruence between biodiversity and ecosystem services are poorly understood, and the little quantitative evidence available so far has led to mixed conclusions (Chan et al. 2006; Metzger et al. 2006). According to the Convention on Biological Diversity's definition of biodiversity and the UK National Ecosystem Assessment report, biodiversity may act as a regulator of underpinning ecosystem processes as a final ecosystem service and as a good that is subjected to valuation, whether economic or otherwise (Mace et al. 2012). Thus, to really understand this complex relationship, we need to develop an interdisciplinary science of ecosystem management, bringing together ecologists, conservation biologists as well as resource economists. Despite these challenges, comparisons between biodiversityrelated and ecosystem service assessments have the potential to viably support decision-making processes. More research on the quantification and mapping of ecosystem services would improve our understanding on synergies and trade-offs between services and biodiversity. Sustainable development should involve managing for both in order to enhance human welfare that is linked in diverse ways to biodiversity, conservation and ecosystem services (Naidoo et al. 2006). 


\section{Applicability and outlook}

Although the methods of the ESS and structural landscape functionality assessments have been specifically targeted to our study region, their overall framework will be applicable in other areas as well. Particularly in protected mountain landscapes, various biotic and abiotic base datasets are often available even on a broader scale, but quantification of specific ESS is still limited or incomplete. There the use of regionally adapted capacity matrices, including appropriate land cover classes, would provide a good overview of trends in ESS provision along and between entire mountain regions. Similarly, the structural assessment of landscape functionality along with the identification of key landscape elements and GI networks for certain target species or guilds could be established. Together, these concepts allow a comprehensive insight into the mutual benefits that landscapes can provide for both society and nature if sustainable development and use of natural resources is guaranteed. As the proposed methods are comprehensible as well as easily applicable along a wide range of different landscapes, it seems that they are well suited for integration into existing ecosystem monitoring techniques.

\section{Acknowledgements}

This study has been conducted within the projects TransEcoNet (Transnational Ecological Networks), which is implemented through the Central Europe Programme co-financed by ERDF, and BIOSERV (Biodiversity of ecosystem services as scientific foundation for the sustainable implementation of the redesigned Biosphere Reserve Neusiedler See) within the Man and Biosphere programme funded by the Austrian Academy of Sciences.

\section{References}

Bunce, R.G.H., M.M.B. Bogers, P. Roche, M. Walczak, I.R. Geijzendorffer \& R.H.G. Jongman 2011. Manual for Habitat and Vegetation Surveillance and Monitoring: Temperate, Mediterranean and Desert Biomes. $1^{\text {st }}$ edition, Wageningen, $\mathrm{Al}$ terra report 2154. Available at: http://www.ebone. wur.nl/NR/rdonlyres/DADAAB1E-F07C-4AA38621-20548A9B7DE6/135332/report2154.pdf (accessed: 17/12/2012)

Bunce, R.G.H., M.J. Metzger, R.H.G. Jongman, J. Brandt, G. De Blust, R. Elena-Rossello, G.B. Groom, L. Halada, G. Hofer, D.C. Howard, P. Kovar, C.A. Mucher, E. Padoa-Schioppa, D. Paelinx, A. Palo, M. Perez-Soba, I. Ramos, P. Roche, H. Skanes \& T. Wrbka 2008. A standardized procedure for surveillance and monitoring European habitats and provision of spatial data. Landscape Ecology 23: 11-25.

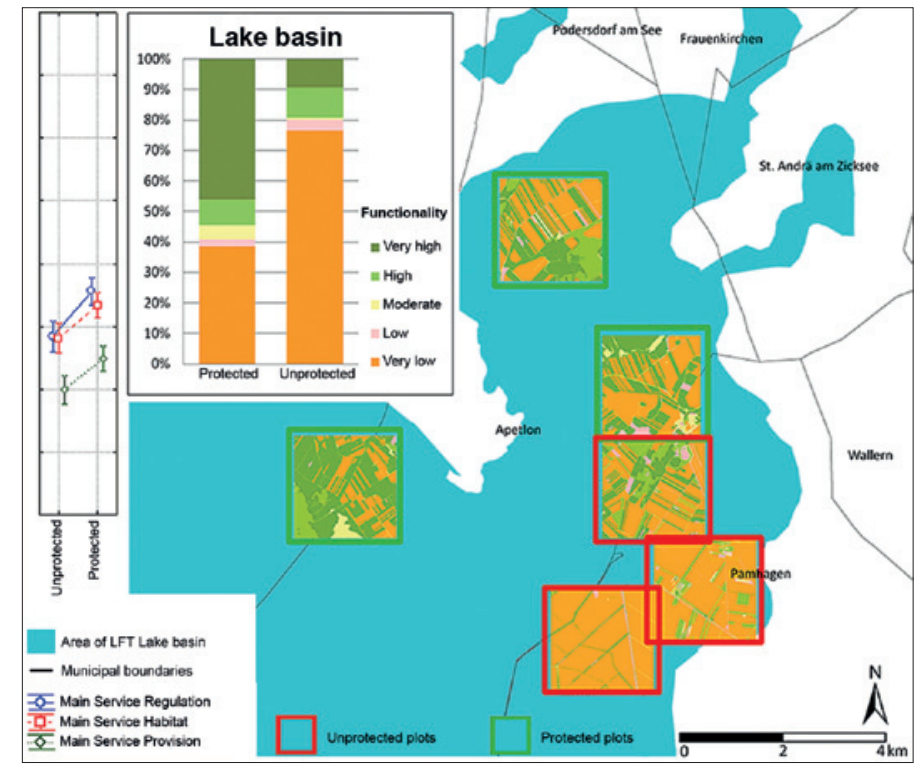

Figure 6 - Overview of the sample plots selected in LFT Lake basin and corresponding structural functionality (histogram) and main ecosystem service distribution charts (boxplot - see also Figure 4), distinguishing between protected and unprotected sites.

Chan, K.M.A., M.R. Shaw, D.R. Cameron, E.C. Underwood \& G.C. Daily 2006. Conservation planning for ecosystem services. PLoS Biology 4 (11): 2138-2152.

Daily, G.C. \& P.A. Matson 2008. Ecosystem services: from theory to implementation. PNAS 105 : 9455-9456.

de Groot, R.S. 2006. Function-analysis and valuation as a tool to assess land use conflicts in planning for sustainable, multi-functional landscapes. Landscape and Urban Planning 75 (3-4): 175-186.

Dudley, N. (ed.) 2008. Guidelines for Applying Protected Area Management Categories. Gland.

Egoh, B., B. Reyers, M. Rouget, D.M. Richardson, D.C. Le Maitre \& A.S. van Jaarsveld 2008. Mapping ecosystem services for planning and management. $A g$ riculture, Ecosystems \& Environment 127 (1-2): 135-140.

Egoh, B., B. Reyers, M. Rouget, M. Bode, D.M. Richardson 2009. Spatial congruence between biodiversity and ecosystem services in South Africa. Biological Conservation 142: 553-562.

Forman, R.T.T. 1995. Land Mosaics - The Ecology of Landscapes and Regions. Cambridge.

Harrison, P.A., M. Vandewalle, M.T. Sykes, P.M. Berry, R. Bugter, F. de Bello, C.K. Feld, U. Grandin, R. Harrington, J.R. Haslett, R.H.G. Jongman, G.W. Luck, P.M. da Silva, M. Moora, J. Settele, J.P. Sousa \& M. Zobel 2010. Identifying and prioritising services in European terrestrial and freshwater ecosystems. Biodiversity and Conservation 19: 2791-2821.

Haslett, J.R., P.M. Berry, G. Bela, R.H.G. Jongman, G. Pataki, M.J. Samways \& M. Zobel 2010. Changing conservation strategies in Europe: a framework integrating ecosystem services and dynamics. Biodiversity and Conservation 19: 2963-2977. 
Hermann A., M. Kuttner, C. Hainz-Renetzeder, E. Konkoly-Gyuró, A. Tirászi, C. Brandenburg, B. Allex, K. Ziener \& T. Wrbka 2014. Assessment framework for landscape services in European cultural landscapes an Austrian Hungarian case study. Ecological Indicators 37: 229-240.

Hermann, A., S. Schleifer \& T. Wrbka 2011. The concept of ecosystem services regarding landscape research: a review. Living Reviews in Landscape Research 5.

Konkoly-Gyuró, E., A. Tirászi, T. Wrbka, M. Prinz \& C. Renetzeder 2010. Der Charakter grenzüberschreitender Landschaften (Határon átivelo tájak karaktere). University of Western Hungary, Sopron.

Kuttner, M., C. Hainz-Renetzeder, A. Hermann \& T. Wrbka 2013. Borders without barriers - Structural functionality and green infrastructure in the Austrian - Hungarian transboundary region of Lake Neusiedl. Ecological Indicators 31: 59-72.

Mace, G.M., K. Norris \& A.H. Fitter 2012. Biodiversity and ecosystem services: a multilayered relationship. Trends in Ecology and Evolution 27 (1): 19-26.

Maes, J., M.L. Paracchini, G. Zulian, M.B. Dunbar \& R. Alkemade 2012. Synergies and trade-offs between ecosystem service supply, biodiversity, and habitat conservation status in Europe. Biological Conservation 155: 1-12.

McGarigal, K., S.A. Cushman, M.C. Neel \& E. Ene 2002. FRAGSTATS: Spatial Pattern Analysis Program for Categorical Maps. Computer Software Program Produced by the Authors at the University of Massachusetts, Amherst.

Metzger, M.J., M.D.A. Rounsevell, L. Acosta-Michlik, R. Leemans \& D. Schrotere 2006. The vulnerability of ecosystem services to land use change. Agriculture Ecosystems and Environment 114 (1): 69-85.

Moser,D., H.G.Zechmeister, C. Plutzar, N. Sauberer, T. Wrbka \& G. Grabherr 2002. Landscape shape complexity as an effective measure for plant species richness in rural landscapes. Landscape Ecology 17: 657-669.

Naidoo, R. \& T.H. Ricketts 2006. Mapping the economic costs and benefits of conservation. PLoS Biology 4 (11): 2153-2164.

Nelson, E., G. Mendoza, J. Regetz, S. Polasky, H. Tallis, D.R. Cameron, K.M.A. Chan, G.C. Daily, J. Goldstein, P.M. Kareiva, E. Lonsdorf, R. Naidoo, T.H. Ricketts \& M.R. Shaw 2009. Modelling multiple ecosystem services, biodiversity conservation, commodity production, and tradeoffs and landscape scales. Frontiers in Ecology and the Environment 7: 4-11.

Otte, A., D. Simmering \& V. Wolters 2007. Biodiversity at the landscape scale: recent concepts and perspectives for multifunctional land use. Landscape Ecology 22: 639-642.

R-Development Core Team 2008. R: A Language and Environment for Statistical Computing. www.r-project. org/
Syrbe, R-U. \& U. Walz 2012. Spatial Indicators for the assessment of ecosystem services: Providing, benefiting and connecting areas and landscape metrics. Ecological Indicators 21: 80-88.

Turner, M.G., R.H. Gardner \& R.V. O’Neill 2001. Landscape Ecology in Theory and Practice, Pattern and Process. New York.

Walz, U. 2011. Landscape structure, landscape metrics and biodiversity. Living in landscape research 5 (3). Available at: http://www.livingreviews.org/lrlr-2011-3 (accessed: 21/03/2014)

Walz, U \& R.-U. Syrbe 2013. Linking landscape structure and biodiversity. Ecological Indicators 31: 1-5.

Wrbka, T., K.H. Erb, N.B. Schulz, J. Peterseil, C. Hahn \& H. Haberl 2004. Linking pattern and process in cultural landscapes. An empirical study based on spatially explicit indicators. Land Use Policy 21 (3): 289-306.

ZAMG 2002. Klimadaten von Österreich 19712000. Zentralanstalt für Meteorologie und Geodynamik, Wien. Available at: http://www.zamg.ac.at/fix/ klima/oe71-00/ (accessed: 21/03/2014)

\section{Authors}

\section{Michael Kuttner*}

is a graduate ecologist and $\mathrm{PhD}$ candidate at the Department of Botany and Biodiversity Research at the University of Vienna. Since 2010 he has worked in the field of landscape and vegetation ecology, focusing on the relation between biodiversity and landscape structures, GIS and species distribution modeling.

\section{Anna Schneidergruber}

is a post-doc researcher at the Department of Botany and Biodiversity Research at the University of Vienna. Her main research interests are landscape and vegetation ecology, with special emphasis on biodiversity and the assessment of ecosystem services.

\section{Thomas Wrbka*}

is senior research fellow and senior lecturer at the Department of Botany and Biodiversity Research at the University of Vienna. His expertise is on classification of Austrian landscapes, development of indicators for sustainable land use, analysis of correlations between land management and biodiversity, vegetation and landscape monitoring and management concepts.

* Faculty Centre of Biodiversity, University of Vienna, Department of Conservation Biology, Vegetationand Landscape Ecology. 